\title{
Contaminated Dietary Supplements
}

\section{Citation}

Cohen, Pieter A. 2019. Contaminated Dietary Supplements. The New England Journal of Medicine 362 (3): 274-274

\section{Permanent link}

http://nrs.harvard.edu/urn-3:HUL.InstRepos:39700398

\section{Terms of Use}

This article was downloaded from Harvard University's DASH repository, and is made available under the terms and conditions applicable to Other Posted Material, as set forth at http:// nrs.harvard.edu/urn-3:HUL.InstRepos:dash.current.terms-of-use\#LAA

\section{Share Your Story}

The Harvard community has made this article openly available.

Please share how this access benefits you. Submit a story.

Accessibility 
2. Thigpen BD, Hood WA, Chauhan S, et al. Timing of prophylactic antibiotic administration in the uninfected laboring gravida: a randomized clinical trial. Am J Obstet Gynecol 2005;192: 1864-8.

3. Wax JR, Hersey K, Philput C, et al. Single dose cefazolin prophylaxis for postcesarean infections: before vs. after cord clamping. J Matern Fetal Med 1997;6:61-5.

4. Sullivan SA, Smith T, Chang E, Hulsey T, Vandorsten JP,
Soper D. Administration of cefazolin prior to skin incision is superior to cefazolin at cord clamping in preventing postcesarean infectious morbidity: a randomized controlled trial. Am J Obstet Gynecol 2007;196(5);455.e1-455.e5. [Erratum, Am J Obstet Gynecol 2007;197:333.]

5. Costantine MM, Rahman M, Ghulmiyah L, et al. Timing of perioperative antibiotics for cesarean delivery: a metaanalysis. Am J Obstet Gynecol 2008;199(3):301.e1-301.e6.

\section{Contaminated Dietary Supplements}

TO THE EDITOR: With regard to the Perspective article by Cohen (Oct. 15 issue) ${ }^{1}$ : I would argue that the challenge posed by the inclusion of undeclared drug ingredients in supplements bears no relation to any purported shortcomings of the Dietary Supplement Health and Education Act (DSHEA). Such practices are already prohibited under federal law, including amendments made by the DSHEA, and they are punishable by civil and criminal penalties. A manufacturer that does not already comply with existing laws should not be expected to comply with new laws. Any new laws would most likely have the perverse effect of placing additional burdens on an overstretched Food and Drug Administration (FDA) and of placing scrupulous supplement manufacturers at a further competitive disadvantage as compared with those who flout the law.

What is needed is not new laws, but a concerted effort to enforce existing laws and to educate consumers so that they can make more informed purchasing decisions. The importance of consumer education cannot be overstated, given the ease with which nearly all products can be marketed and purchased over the Internet. As noted by Cohen, these are efforts in which physicians can play a valuable role.

Ricardo Carvajal, J.D.

Hyman, Phelps, and McNamara

Washington, DC

rcarvajal@hpm.com

As an attorney, the author provides regulatory counseling to manufacturers and marketers of dietary supplements. No other potential conflict of interest relevant to this letter was reported.

1. Cohen PA. American roulette - contaminated dietary supplements. N Engl J Med 2009;361:1523-5.

THE AUTHOR REPLIES: I agree that aggressive enforcement and consumer and physician education are important. However, Carvajal's claim that unsafe dietary supplements are available solely because of lax FDA enforcement is inaccurate..$^{1,2}$ The DSHEA assumes that all dietary supplements are safe until proved harmful. ${ }^{3}$ Unfortunately, this assumption creates a facade of safety for both legal and illegal dietary supplements.

Regulatory frameworks can encourage or discourage the availability of product information. ${ }^{4}$ Regulation that includes premarket testing of safety can ensure that accurate and informative product information is available. Currently, consumers and physicians remain uninformed because premarket testing of supplement safety is not required. ${ }^{3}$ This asymmetry of information between sellers and consumers leads to domination of the market by low-quality products because the regulatory framework creates financial disincentives to sell high-quality supplements. ${ }^{5}$

Both regulatory reform and aggressive enforcement are required to enhance the overall quality of dietary supplements and to provide accurate safety information.

Pieter Cohen, M.D.

\section{Cambridge Health Alliance}

Cambridge, MA

Since publication of his article, the author reports no further potential conflict of interest.

1. Gardiner P, Sarma DN, Low Dog T, et al. The state of dietary supplement adverse event reporting in the United States. Pharmacoepidemiol Drug Saf 2008;17:962-70.

2. Miller RK, Celestino C, Giancaspro GI, Williams RL. FDA's dietary supplement CGMPs: standards without standardization. Food Drug Law J 2008;63:929-42.

3. Cohen PJ. Science, politics and the regulation of dietary supplements: it's time to repeal DSHEA. Am J Law Med 2005; 31:175-214.

4. Carpenter D. Confidence games: how does regulation constitute markets? In: Balleisen EJ, Moss DA, eds. Government and markets: towards a new theory of regulation. New York: Cambridge University Press, 2009:164-92.

5. Akerlof GA. The market for "lemons": quality uncertainty and the market mechanism. Q J Econ 1970;84:488-500. 